\title{
Verb-Framed Motion Events in Uralic (with special attention to Mari)
}

Uralic languages have been described as "satellite-framed" in general linguistic publications, meaning that the path of a motion event is typically not expressed by the verb of motion, but by an independent element - a particle, an affix, etc. - that accompanies the verb or verbal stem. While this assertion holds true for the critical mass of Uralic languages, it seems to be too broad - especially with respect to languages influenced by "verb-framed" Turkic languages, in which the verb of motion typically denotes the path. This paper aims to give a comprehensive overview of the expression of motion events in Mari, the presumably most heavily verb-framed extant Uralic language, and a brief overview of verb-framed motion events in other Uralic languages.

1. Verb-Framing and Satellite-Framing

2. Turkic Verb-Framing

3. Motion Events in Mari

4. Verb-Framing Elsewhere
4.1 Udmurt

4.2 Mordvin

4.3 Samoyedic

4.4 Finnic

5. Conclusions

\section{Verb-Framing and Satellite-Framing}

Leonard Talmy's typological classification of motion events seeks to demonstrate "the existence and nature of certain semantic categories such as 'Motion event', 'Figure', 'Ground', 'Path', 'Co-event', 'Precursion', 'Enablement', 'Cause', 'Manner', 'Personation', etc.” (Talmy 2007: 167), within a cognitive linguistic framework. He defines the principle of a 'Motion event' as follows:

To begin with, we treat a situation containing motion or the continuation of a stationary location alike as a 'Motion event' (with a capital 'M'). The basic Motion event consists of one object (the 'Figure') moving or located with respect to another object (the reference-object or 'Ground'). It is analysed as having four components: besides 
Verb-Framed Motion Events in Uralic (with special attention to Mari)

'Figure' and 'Ground', there are 'Path' and 'Motion'. The 'Path' (with a capital 'P') is the path followed or site occupied by the Figure object with respect to the Ground object. 'Motion' (with a capital 'M') refers to the presence per se of motion or locatedness in the event. [...] In addition to these internal components, a Motion event can be associated with an external 'Co-event' that most often bears the relation of 'Manner' or of 'Cause' to it. (Talmy 2007: 66, cf. also Talmy 1985)

Luna Filipović expands upon Talmy's framework, and gives the following definitions of the basic components listed by him:

Motion: Presence of motion

Figure: The moving object

Ground: The reference-point object with respect to which the Figure moves

Path: The course followed by the Figure with respect to the Ground

(Filipović 2007: 17)

When analysing the realization of these concepts (and 'Manner') in different languages, Talmy makes a rough distinction between what he calls verb-framed and satellite-framed systems (Talmy 2007: 153), depending on the preference a language has for the structuring of these components. Dan I. Slobin follows his lead (though he does not refer to the ground, but rather to the source or goal of a motion event) and illustrates the difference between a satellite-framed system - English - and a verb-framed system Spanish - graphically:

\begin{tabular}{|ccc|}
\hline MOTION, MANNER & PATH & SOURCE/GOAL \\
$\downarrow$ & $\downarrow$ & $\downarrow$ \\
VERB $_{\text {finite }}{ }^{2}$ & SATELLITE & $\mathrm{N}+$ (adposition, case) \\
$\downarrow$ & $\downarrow$ & $\downarrow$ \\
go, run & out & of the house \\
go, run & in & to the house \\
\hline
\end{tabular}

Figure 1: English motion events: satellite-framed (Slobin 2000:109)

\begin{tabular}{|ccc|}
\hline MOTION, PATH & SOURCE/GOAL & MANNER \\
$\downarrow$ & $\downarrow$ & $\downarrow$ \\
$\mathrm{VERB}_{\text {finite }}$ & $\mathrm{N}+$ (adposition, case) & $\mathrm{VERB}_{\text {nonfinite }}$ \\
$\downarrow$ & $\downarrow$ & $\downarrow$ \\
salir 'exit' & de la casa 'of the house' & corriendo 'running' \\
entrar 'enter' & en la casa 'in the house' & corriendo 'running' \\
\hline
\end{tabular}

Figure 2: Spanish motion events: verb-framed (Slobin 2000: 109) 
In satellite-framed languages like English, the path preferentially (see discussion below) is defined by a "satellite" of the verb, while verb-framed languages like Spanish preferentially indicate the path with the main verb of the clause (Slobin 2000: 108). The satellite, in this nomenclature, "is the grammatical category of any constituent other than a nominal complement that is in a sister relation to the verb root" (Talmy 2007: 139) and "can be either a bound affix or a free word, [and] is thus intended to encompass all of the following grammatical forms, which traditionally have been largely treated independently of each other: English verb particles, German separable and inseparable verb prefixes, Latin or Russian verb prefixes, [...]" (ibid.).

When distinguishing between satellite-framed languages and verbframed languages, Talmy and Slobin are by their own admission primarily describing tendencies rather than clear-cut distinctions. Slobin speaks of manner verbs (e.g. run, fly) and path verbs (e.g. enter, exit) depending on what semantic concepts the verbs express (Slobin 2000: 113). Satelliteframed languages prefer to use manner verbs as the main verb, while verbframed languages prefer to use path verbs as the main verb (ibid.: 108). For the languages he directly studies (English, German, Dutch, Russian, French, Spanish, Turkish, Hebrew), Slobin evaluates the relative frequency of manner verbs and path verbs within his elicited data. The strength of this preference, he observes, differs from language to language. Whereas Russian seems to be strictly satellite-framed - 100\% of motion verbs are manner verbs within his data - and Spanish seems to be strictly verbframed $-100 \%$ of motion verbs are path verbs within his data (ibid.: 113), English is subject to considerable variance, with both satellite-framed and verb-framed constructions being widely used:

English

(1) The mouse ran into the hole. (Satellite-framed construction)

The mouse came running into the hole. (Verb-framed construction)

Among the body of text collected by Slobin in his research work, in fact only $32 \%$ of English motion verbs are manner verbs (typical of satelliteframed constructions), and $68 \%$ are path verbs (ibid.) - his classification of English as a satellite-framed language notwithstanding.

Acknowledging that he is describing trends rather than deterministic rules, Slobin labels Germanic, Slavic, and "Finno-Ugric" languages as satellite-framed, but Turkish as verb-framed, like Spanish (ibid.: 109). This 
classification of Finno-Ugric as satellite-framed has been picked up by other authors (e.g. Asbury et al. 2008: 21; Filipović 2007: 19), and likewise by Talmy (Talmy 2007: 72) - although no sources are given to support this claim. Perhaps Slobin based this assertion on personal correspondence with colleagues, familiarity with some Uralic languages, and/or sources on individual Uralic languages, rather than on a systematic survey of all the languages of this phylum. This is understandable, if not inevitable, given the state of research: Surveys exist on motion events in individual Uralic languages (e.g. Pajusalu et al. 2013 for Estonian) and comparative studies of a limited scope have been carried out for a few Uralic languages (Söder 2001 for Hungarian, Northern Khanty, Northern Saami; Lander et al. 2013 for verbs of aquamotion in Finnish, Komi-Zyrian, Nganasan, Selkup, and Udmurt, and numerous non-Uralic languages). There is, however, no typological contrastive review of the verbalization of motion events in Uralic in general.

Slobin's statement, as a description of a tendency, seems intuitively correct in reference to many Uralic languages. The extensive system of pathmarking verbal prefixes found in the Ugric languages - Hungarian, Mansi, Khanty - are unambiguous satellites (cf. Honti 1999: 86-91). Estonian (see below) makes extensive use of satellites as well, and manner verbs seem to dominate over path verbs in Finnish. Satellite-framing indeed seems to be the prototypically Uralic approach to motion events.

\begin{tabular}{|ccc|}
\hline MOTION, MANNER & SOURCE/GOAL & PATH \\
$\downarrow$ & $\downarrow$ & $\downarrow$ \\
VERB $_{\text {finite }}$ & $\mathrm{N}+$ (adposition, case) & SATELLITE \\
$\downarrow$ & $\downarrow$ & $\downarrow$ \\
jooksin 'I ran' & majast 'out of the house' & välja 'out' \\
jooksin 'I ran' & majja 'into the house' & sisse 'into' \\
\hline
\end{tabular}

Figure 3: Estonian motion events, following Talmy and Slobin's nomenclature $^{3}$

Classifying Uralic (or Finno-Ugric) languages collectively as satelliteframed is, however, going a step too far, especially in light of the heavy structural borrowing that has occurred from strongly verb-framed Turkic languages into some Uralic languages. The statement does not hold true at all in at least one Uralic language: Mari, a language with a strong inclination to verb-framed constructions, as will be shown below. In other 
Uralic languages influenced by Turkic (Udmurt, Erzya, Kamass, Selkup), verb-framed constructions of the Turkic type seem to be less dominant, but potential occurrences can be found. After introducing the Turkic type of verb-framing, this paper will seek to provide a detailed summary of the expression of motion events in Mari and a brief overview of verb-framed structures found in other Uralic languages.

\section{Turkic Verb-Framing}

Dan I. Slobin and his colleagues made use of a picture storybook in their survey of verb- and satellite-framing in a number of languages (English, German, Dutch, Russian, French, Spanish, Turkish, Hebrew): children aged 3 to 11 and adult speakers were asked to describe the fairy tale-type plot set out in the book. One and the same event was described by speakers of English as an owl flying out of a hole in a tree, but by speakers of verbframed Turkish as follows:

Turkish $^{4}$ (Slobin 200o: 112)

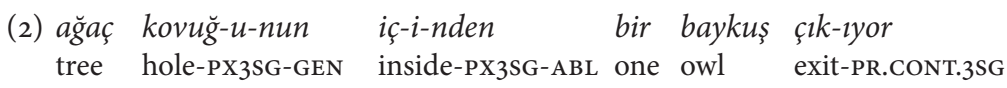

'The owl flew out (lit. exited) of the hole in the tree.'

The path, expressed by the satellite out in English, is expressed by the finite verb in Turkish. The manner is not expressed here, but is rather left to context - i.e. it is treated as optional information that can be expressed if need be. In this particular case, this information is rather semantically "light", as flying is a natural manner of movement for an owl, much like swimming could be considered the natural manner of movement for a fish, floating for a raft, etc. Perhaps this predetermination is a factor in the omission of this information that the usage of a path verb allows.

If the manner of a motion is given, Turkish uses a converb5:

Turkish (Schroeder 2009: 186)

(3) $[k]$ oş-arak ev-e gir-di

run-CVB house-DAT enter-PST.3SG

'S/he ran into (lit. entered running) the house.'

While there are some differences with respect to word order, this general strategy is also employed by the Turkic languages of the Volga area: Tatar and Bashkir, two closely related Volga Kipchak languages (cf. Berta 
1998: 283), and Chuvash, which is genealogically quite distant from all its relatives (cf. Kornfilt 2009: 519) and the only extant representative of the Bolgar Turkic (Oghur/Lir) subgroup (cf. Schönig 1997-1998: I: 121):

Tatar (ABBYY 2014: залететь)
(4) qoš
täräzä-dän oś-op
ker-de
bird
window-ABL
fly-CvB
enter-PST.3SG

'The bird flew in (lit. flying entered) through the window.'

Bashkir (Miščenko 2014: 1)

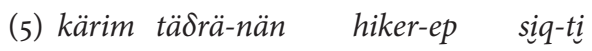

Kärim window-ABL jump-CvB exit-PST.3sg

'Kärim jumped out (lit. jumping exited) the window.'

Chuvash (Skvorcov \& Skvorcova 2002: вылететь)
(6) čěkeś
jăv-in-čen
věś-se

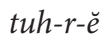
swallow
nest-PX3SG-ABL
fly-CvB
exit-PST-3SG
'The swallow flew out of (lit. flying exited) its nest.'

\section{Motion Events in Mari}

The intense influence of Turkic languages on Mari lexicology, phonology, and morphology has been intensively studied over the course of the last century. Several monographs have been written about Turkic loan words in Mari (e.g. Räsänen 1920, 1923; Isanbaev 1989-1994), and the diffusion of different loan word layers has been analysed and compared (e.g. Saarinen 1997a, 2010). The parallel development of vowel systems in the languages of the Volga region has been studied (e.g. Johanson 2000), as has the loaning of suffixes from Turkic languages into Mari and the distribution of Turkic loan translations in Mari (e.g. Saarinen 1997b; Hesselbäck 2005). The comparative study of syntax and semantics is still at a rather nascent stage. Given the Mari language's well-established status as a heavily "Turkified" Uralic language, however, it is a logical starting point for a survey of the proliferation of a Turkic structure in Uralic. As different Turkic languages of the region employ the same strategy in the verbalization of motion events, a historical survey of Turkic-Mari language contact (in which Bolgar Turkic was eventually replaced by Kipchak Turkic as the phylum exerting influence on Proto-Mari) will be omitted here. 
For readers not fully acquainted with both the Mari and the Russian languages, the entry on the verb tolam 'to come' in the largest Mari-Russian dictionary published to date can be daunting. It spans over seven pages (Galkin et al. 1990-2005: VII: 132-138) and gives 28 distinct aspects of meaning as translations. While a novice's assumption might be that the Mari verb is ridiculously ambiguous or that the Russian lexicon is ridiculously detailed, the explanation of this phenomenon lies rather in the different manner in which motion events are expressed in these two languages. The following excerpt from the entry illustrates this point (forms that would unnecessarily complicate the picture have been excluded):

\begin{tabular}{|c|c|c|}
\hline & {$[\ldots]$ prixodit' $[\ldots]$} & 'to come (walking)' \\
\hline 2. & {$[\ldots]$ prijexat' $[\ldots]$} & 'to come (by vehicle/horse)' \\
\hline 3. & {$[\ldots]$} & \\
\hline 4. & {$[\ldots]$ priletet' $[\ldots]$} & 'to come (flying)' \\
\hline 5. & {$[\ldots]$} & \\
\hline 6. & {$[\ldots]$ priplit' $[\ldots]$} & 'to come (swimming)' \\
\hline 7. & {$[\ldots]$} & \\
\hline
\end{tabular}

Figure 4: tolam (Galkin et al. 1990-2005:VII:132-138), with English translations of the Russian translations

As can be seen in this illustration, the (admittedly pre-selected) Russian translations all feature the prefix pri-. This is not a coincidence. The stems of Russian verbs of motion intrinsically mark a manner of transport, but not the path (cf. Wade 2002: 150): ұodit' to go (on foot)', jexat' 'to travel' (i.e. drive, ride), letet' 'to fly', plit' ' to swim'. The prefix pri- is the satellite indicating an 'arrival' (ibid.: 156), and is consequently on its own the actual optimal translation for the Mari verb tolam (and the English verb 'to come').

Mari does of course have means of marking a manner of transport. While the verb tolam indicates the path but not the manner, the verb ćoneštem 'to fly' is the exact opposite: it indicates the manner, but not the path. That is to say, tolam is a path verb and ćoneštem is a manner verb. Both of these verbs can be used on their own as predicates in simple clauses, leaving the dimension they do not mark to context (or disregarding it as it is not relevant to the statement). To mark both the path and the manner, a manner verb - in the form of the converb in - $n$ (cf. Alhoniemi 1985: 141-144) - is followed by a path verb. Figure 5 summarizes the possibilities; examples (7-9) below show the different options covered by this table in sentences. 
Verb-Framed Motion Events in Uralic (with special attention to Mari)

\begin{tabular}{|l|l|l|}
\cline { 2 - 3 } \multicolumn{1}{c|}{} & Path $[+/-]$ & Manner [+/-] \\
\hline tolam 'to come' & + & - \\
\hline ćoneštem 'to fly' & - & + \\
\hline ćoyešten tolam 'to come flying' & + & + \\
\hline
\end{tabular}

Figure 5: Marking path and manner in Mari.

Mari (Sentences provided by Mari native speaker Emma Yakimova)

(7) turńa-ßlak ćoješt-at

crane-PL fly-3PL

'Cranes are flying.'

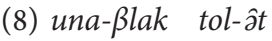

guest-PL come-3PL

'The guests arrive.'

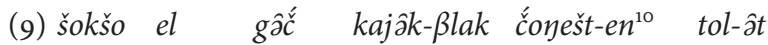
hot land from bird-PL fly-CVB come-3PL

'Birds come flying from warmer countries.'

Example (9) is the structural equivalent of the Volgaic Turkic verb-framed constructions detailed above. An abstraction of the pattern is as follows:

\begin{tabular}{|ccc|}
\hline SOURCE/GOAL & MOTION, MANNER & PATH \\
$\downarrow$ & $\downarrow$ & $\downarrow$ \\
$\mathrm{N}+($ adposition, case) & $\mathrm{VERB}_{\text {nonfinite }}$ & $\mathrm{VERB}_{\text {auxiliary }}$ \\
$\downarrow$ & $\downarrow$ & $\downarrow$ \\
pört gấc 'out of the house' & kuržân 'running' & lektam 'to go out' \\
pört 'šs 'into the house' & kuržân 'running' & purem 'to go in' \\
\hline
\end{tabular}

Figure 6: Mari motion events ${ }^{11}$

Constructions of this type are possible not only with intransitive verbs of self-motion, but also with transitive verbs denoting the movement of something somewhere. It seems that the manner-marking converb and the path verb must agree in transitivity. For example, the verbs $\beta$ olem 'to descend' and $\beta$ oltem 'to bring down ${ }^{12}$ are counterparts: the first is only coupled with intransitive verbs of self-motion, whereas the second verb is only coupled with transitive verbs. The English satellite carrying the same semantics - "down" - is not subject to such a distinction. 


\section{Jeremy Bradley}

Mari (sentences provided by Mari native speaker Tatyana Yefremova)

(10) vaśa pušenge gấ $\quad$ töršt-en $\beta$ Bol-en
Vasya tree out.of jump-cvB descend-PST2.3sG
'Vasya jumped down from the tree.'

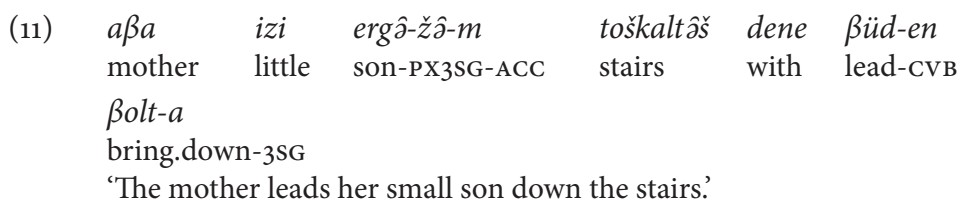

While sentences of this type - transitive and intransitive alike - are ubiquitous in Mari, they have to the best of my knowledge not been studied systematically, and as a rule, are only covered by reference materials implicitly. Generally speaking, motion events are not explicitly discussed in the major reference materials on Mari at all - understandably so, as some of them predate Talmy's research. Information on them is oftentimes implicitly found in an unexpected place, however: in discussions on the realization of verbal aspect ${ }^{13}$.

This is due to the fact that both aspect and motion events are expressed in formally identical verbal pairings, and sources often fail to distinguish between different constructions of this kind on the basis of the semantics expressed. Mari makes extensive use of a structure referred to as aspectual converb construction in some sources (cf. Bradley 2015) and paired verbs in others (cf. Driussi 1993) - to name just a few of the many labels attached to this feature. The following is an example of the phenomenon:

Mari (Riese \& Bradley \& Guseva 2014-: йӧратаи (-ем))

üdâr rßezô-m jörat-en šând-en
girl boy-ACC love-CvB place-PsT2.3sG
'The girl fell in love (loving placed) with the boy'.

Alho Alhoniemi's Finnish-language grammar of the Mari language (Alhoniemi 1985), which thanks to its German translation (Alhoniemi 1993) is still the most extensive, modern, and qualitative resource on Mari grammar at least marginally accessible to the international linguistic community, explains the mechanism as follows:

[The converb in - $n$ ] appears in the so-called aspectual converb construction. Here the syntactic main verb is a verb that gives the activity an aspectual colouring; the 
gerund [converb] contains the semantic content of the construction. Many verbs are used as aspect givers. In the aspectual converb construction, they lose their lexical meaning either entirely or at least partially. Some studies cite as many as 40 such verbs $[\ldots]^{14}$ (Alhoniemi 1985: 143-144)

Alhoniemi then proceeds to list a total of 39 verbs that he considers prospective aspect givers, stating explicitly that this list is surely not exhaustive $e^{15}$ (ibid.). He translates the verbs' core semantics, but does not comment on their usage as an auxiliary in most of the individual instances. Three of the verbs he gives are particularly noteworthy; they are highlighted in grey in the following table:

\begin{tabular}{|c|c|c|}
\hline Bolem 'to descend' & kâškem 'to throw' & $\begin{array}{l}\text { sitarem 'to provide } \\
\text { (as needed)' }\end{array}$ \\
\hline Boltem 'to lower' & lektam 'to go; to appear' & šinč́am 'to sit down' \\
\hline Bozam 'to lie down' & luktam 'to lead out' & šinem 'to sit' \\
\hline ertarem 'to spend (time)' & mijem 'to come, to go' & šogalam 'to stand up' \\
\hline ertem 'to pass' & nalam 'to take' & šogaltem 'to stand sth.' \\
\hline ilem 'to live' & onćem 'to look' & šogem 'to stand' \\
\hline kajem 'to go (away)' & optem 'to pile sth. up' & šuam 'to reach' \\
\hline kijem 'to lie' & puem 'to give' & šuem 'to throw' \\
\hline kodam 'to stay' & pâštem 'to put' & $\begin{array}{l}\text { šuktem 'to carry } \\
\text { out; to make it' }\end{array}$ \\
\hline kodem 'to leave sth.' & pâtarem 'to finish sth.' & šândem 'to put' \\
\hline koltem 'to send' & pâtem 'to end' & temam 'to fill up' \\
\hline koštam 'to go (habitually)' & purem 'to go in' & temem 'to fill sth. up' \\
\hline kudaltem 'to throw' & purtem 'to bring in' & tolam 'to come' \\
\hline
\end{tabular}

Figure 7: Alhoniemi's aspectual markers ${ }^{16}$ (Alhoniemi 1985: 144)

According to my systematic review of verbs listed as aspect givers in different sources (Bradley 2015), the critical mass of the verbs Alhoniemi lists - some of which are path verbs (e.g. kajem 'to go (away)', tolam 'to come') - can occur as markers of aspectual values. Some of the path verbs can occur either as aspectual markers, or as path markers, and the distinction between aspectual and directional constructions can be difficult or impossible in some situations: even native speakers can read either an 
aspectual value, or a path value (or both) into a verbal pairing, as these values do not actually exclude one another. However, I found no plausible indication that these three verbs are ever used to mark aspect, even under the most liberal interpretations of the term. Rather, when these verbs occur in verbal pairings with the converb in $-n$, it is in motion events, as detailed above:

Mari (Riese \& Bradley \& Guseva 2014-: чонешташ (-ем))

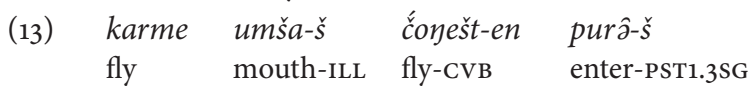

'The fly flew into (flying entered) (his/her) mouth.'

On a spectrum ranging from "pure" aspectual markers (e.g. šândem 'to put') - possibly with some facets of the verb's lexical meaning being retained in some cases (cf. Schönig 1984: 73 for an extensive discussion of this phenomenon in Tatar) - over verbs that express either or both aspectual and path values (e.g. tolam 'to come') to verbs that primarily occur as path verbs in the verb-framed verbalization of motion events (possibly with a secondary aspectual value being expressed), the three highlighted verbs seem to be very much on the "path verb only" side of the spectrum - I have seen no evidence of them expressing aspectual values directly, and Nikolai Isanbaev's earlier surveys on what Alhoniemi calls converb constructions classify them as path markers (Isanbaev 1978: 70-71).

It seems odd that Alhoniemi would conflate such a distinct semantic concept with what he labels as aspect, but he is hardly alone in doing so.

A peculiar form of Mari word formation is represented by the so-called paired verbs. The first component of paired verbs is always an adverbial participle [converb], while the second one takes on the time and mood markers as well as the personal endings. In most cases the second component partially or completely loses its independence and changes the verb's aspect, as Hungarian verbal prefixes do, e.g. M ćonešten kaj $[\mathrm{em}]^{17}$, $\mathrm{H}$ čongešt $[e] n$ ke $[\mathrm{em}]$ 'to fly away' (M ćoneštem, $\mathrm{H}$ čongeštem 'to fly'; $\mathrm{M}$ kajem, $\mathrm{H}$ keem 'to go'); $\mathrm{M}$ šortân koltem, $\mathrm{H}$ mäg[a]r[e]n koltem 'to break out in tears' ( $\mathrm{M}$ šortam, $\mathrm{H}$ mäg[a]rem 'to cry'; M, H koltem 'to send'); [... $]^{18}$ (Bereczki 1990: 73)

While the auxiliary in the second pairing in the quotation above seems to mark aspect, the second verb of the first pairing definitely indicates the path. It should be noted that the verb kajem 'to go', here used as a path verb, can indicate aspect, but it does not here - as Bereczki's Hungarian translation indicates. 
A similar shared treatment of these concepts can be found in Russianlanguage publications. Countless verbal pairings containing a path verb in the second position are placed under the rubric of "aspectual" constructions in reference materials. The article on the verb ćoyeštem 'to fly' in the Mari-Russian dictionary mentioned above marks all the following converb constructions explicitly as "aspectual verbal pairings"19:

\begin{tabular}{|c|c|c|}
\hline Mari verbal pairing & Russian translation & $\begin{array}{l}\text { Idiomatic English } \\
\text { translation }\end{array}$ \\
\hline $\begin{array}{l}\text { ćonešten ßolem } \\
\text { "flying descend" }\end{array}$ & sletat' "from-fly" & 'to fly down' \\
\hline $\begin{array}{l}\text { ćonešten kajem } \\
\text { "flying go (away)" }\end{array}$ & uletat' "away-fly" & 'to fly away' \\
\hline $\begin{array}{l}\text { ćoyešten küzem } \\
\text { "flying rise" }\end{array}$ & vzletat' "up-fly" & 'to fly up' \\
\hline $\begin{array}{l}\text { ćonešten kânelam } \\
\text { "flying get up" }\end{array}$ & vzletat' "up-fly" & 'to fly up' \\
\hline $\begin{array}{l}\text { ćonešten lektam } \\
\text { "flying leave" }\end{array}$ & viletet' "out-fly" & 'to fly out' \\
\hline $\begin{array}{l}\text { ćonešten mijem } \\
\text { 'flying come/go' }\end{array}$ & podletat' "closer-fly" & 'to fly up to sth.' \\
\hline $\begin{array}{l}\text { ćoyešten purem } \\
\text { "flying enter" }\end{array}$ & vletat' “in-fly" & 'to fly in' \\
\hline $\begin{array}{l}\text { ćoyešten tolam } \\
\text { "flying come" }\end{array}$ & priletat' "to-fly" & 'to come flying' \\
\hline $\begin{array}{l}\text { ćonešten ertem } \\
\text { "flying go through" }\end{array}$ & proletat' "through-fly" & 'to fly by/through' \\
\hline
\end{tabular}

Figure 8: Path verbs labelled as aspectual markers (Galkin et al. 1990-2005: VIII: 398-399)

A number of explanations for this phenomenon suggest themselves. The Mari-Russian dictionary cited here was compiled by over a dozen different editors over the span of decades. It cannot be assumed that everyone involved at different times had the same understanding of the terms defined in the dictionary's introduction. And yet, it is odd that a somewhat indifferent approach towards the dividing line between aspect on the one hand and path on the other is so widespread. The Russian translations of 


\section{Jeremy Bradley}

the Mari converb constructions given in Figure 8 above hint at another possible explanation: path is marked by verbal prefixes in Russian, much as aspect is in many cases. In fact, the very same verbal prefixes, often associated with specific prepositions (Tolskaya 2007: 347), occur as path markers and as aspectual markers in Russian. It is not at all unusual for path-marking elements - be they adpositions, spatial adverbs, or verbs of motions - to be grammaticalized as markers of more abstract semantic categories, such as tense, aspect, mood (TAM), etc., and this has been extensively studied cross-linguistically (e.g. Devos \& van der Wal 2014). Examples can easily be found in the "western" Uralic languages as well:

Hungarian (Forgács 2007: 245)

(14) $\begin{aligned} & \text { el-szak-it } \\ & \text { away-part-CAUs } \\ & \text { 'to tear apart'o }\end{aligned}$

(15) el-törik away-break 'to break apart'21

In fact, one need not look any further than English to find examples of motion-marking elements being used as TAM markers.

English

(16) Help! Help! I am going to drown!

(17) You bastard, you ate up all the cookies.

It thus seems almost understandable that path-marking elements have been interpreted as TAM-marking elements in Mari, even in the complete absence of evidence that they have any such functions. Moreover, numerous verbs of motion are indeed used as aspect givers, for instance in the following example, where the verb kajem is used to denote a "momentary action that leads to a result"22 (Alhoniemi 1985: 144):

Mari (Alhoniemi 1985: 144)

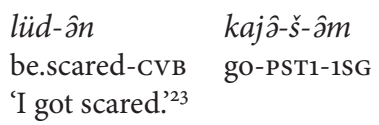

The manner in which this particular verb - kajem 'to go' - was grammaticalized as an aspectual auxiliary is not immediately clear. The grammaticalization of verbs meaning 'to leave' or 'to exit' as a terminative/completive/egressive marker has been observed cross-linguistically (Heine \& Kuteva 2002: 189-190); Tatar kitü 'to go (away)' and Chuvash kaj 'id.' are 
Verb-Framed Motion Events in Uralic (with special attention to Mari)

used as aspectual modifiers with a comparable range of functions (Isanbaev 1978: 62-63), as is Udmurt koškini 'id.' (Kel'makov 1975: 95). There could well have been a parallel grammaticalization of these path verbs as aspectual auxiliaries under the pressure of tendencies that have been observed cross-linguistically, in all of these languages ${ }^{24}$. Alternatively, $\mathrm{kajem}$ as an aspectual auxiliary could be the product of contact-induced grammaticalization - i.e. its usage in aspectual constructions could be the result of loan translations from Turkic, rather than an intra-language grammaticalization of a path verb as an aspectual modifier. The latter theory is supported by the identification of numerous specific verbal pairings as loan translations from Chuvash (cf. Bereczki et al. 2013); these calques might have served as a starting point for contact-induced grammaticalization.

When reviewing a wide array of reference materials on Mari, in the attempt to distinguish converb constructions by their semantics (cf. Bradley 2015), I found the verbs included in the following table (Figure 9) - some, but not all, of which are also used as aspect markers - used as path verbs in combination with a manner-marking converb in $-n$. The English translations given in the "path" column are the satellites that can be used in English counterparts to the verb-framed Mari constructions. The set of verbs that can occur as the manner-marking converb seems to be more open, within semantic restrictions. It seems that any verb to which a path can be assigned can occur in this position.

It should be noted that some of the path verbs indicate the direction in relation to the deictic centre (i.e. movement to or from a reference point), while others indicate the direction in relation to topological coordinates (i.e. up/down/etc. in an absolute sense). As Mari does not seem to make a distinction between these kinds of path verbs, I will continue subsuming these two classes of path verbs.

The etymological relationship between an intransitive path verb and a transitive path verb varies from pairing to pairing: transitive $\beta$ oltem and purtem are derived from their intransitive counterparts by means of the partially productive causative suffix $-t \sim-d$ (cf. Alhoniemi 1985: 164-165). Transitive küzojktem is derived from its intransitive counterpart using the fully productive causative suffix $-k t$ (cf. ibid.: 163). The transitive verbs namijem and naygajem were originally verbal pairings consisting of the converb in $-n$ of the verb nalam 'to take' and their intransitive counterparts: nalân mijem "to taking come" and nalân kajem "to taking go" (Alhoniemi 1986: 102). In two cases, the intransitive verb has been derived from its 


\section{Jeremy Bradley}

\begin{tabular}{|c|c|c|}
\hline Path & Intransitive & Transitive \\
\hline down, downwards & Bolem 'to descend, to sink' & Boltem 'to lower sth.' \\
\hline in, into & purem 'to go in, to enter' & purtem 'to bring sth. in' \\
\hline up & küzem 'to rise, to climb' & küzว̂ktem 'to raise, to lift' \\
\hline up to & mijem 'to come, to go' & $\begin{array}{l}\text { namijem 'to bring, to } \\
\text { deliver' }\end{array}$ \\
\hline away & kajem 'to go, to leave' & $\begin{array}{l}\text { naygajem 'to take (sth. } \\
\text { somewhere)' }\end{array}$ \\
\hline apart & ojârlem 'to go apart' & ojârem 'to separate' \\
\hline through (perforating) & šütlem 'to be pierced' & šütem 'to pierce' \\
\hline out & lektam 'to go, to leave' & $\begin{array}{l}\text { luktam 'to lead out, to } \\
\text { remove' }\end{array}$ \\
\hline (coming) & tolam 'to come' & kondem 'to bring' \\
\hline across, over & ßončem 'to go over' & - \\
\hline past, by & ertem 'to go by' & - \\
\hline
\end{tabular}

Figure 9: Path verbs in Mari that are paired with manner-marking converbs $^{25}$

transitive counterpart by means of a derivational suffix $-l$ not described in Alhoniemi's grammar. In two cases each, there is either no or at least no clear etymological connection or there is no transitive counterpart to an intransitive path verb.

Not all verbal pairings denoting a movement follow the very productive pattern established here. Note, for example, the following pairings, where both verbs represent the category of path-marking verbs:

Mari (sentences provided by Mari native speaker Tatyana Yefremova)

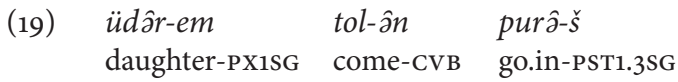

'My daughter came in (coming entered).' 
Verb-Framed Motion Events in Uralic (with special attention to Mari)

$(20)$

$\begin{array}{lllll}\text { ajßika ojlâ-š } & \text { pujto tudo } & \text { pariž-âš } & \text { mij-en } & \text { tol-ân } \\ \text { Ayvika say-PST1.3sG that s/he } & \text { paris-ILL } & \text { go-CVB } & \text { come-PST2.3SG } \\ \text { 'Ayvika said that she went to Paris.' } & & & \end{array}$

As can be said of many verbal pairings, these examples are clear Turkic loan translations: tolân purem 'to come in (coming enter)' < Chuvash kilse kĕr id. ${ }^{26}$ (Bereczki et al. 2013: 279), mijen tolam 'to go, to visit' (lit. "to going come") < Chuvash pïrsa kil id. ${ }^{27}$ (ibid.: 142). Other pairings of this kind include lektân kajem 'to go out, to go away (leaving go) ${ }^{28}$, tolân šuam 'to arrive (coming arrive) ${ }^{29}$, mijen purem 'to visit (coming enter) ${ }^{30}$, mijen šuam 'to reach, to arrive at (going arrive) '31, puren lektam 'to drop in, to visit (entering leave) ${ }^{32}$. In contrast to the productive pattern detailed above, I cannot observe an abstract pattern governing the usage of these pairings and am inclined to consider them to be individual phraseological expressions/loan translations.

In spite of the observations on the combinability of path verbs and motion verbs made in this chapter, a quantitative study of the relative frequency of verbs of this type as the finite verb of a clause could be expected to yield interesting results. It would be especially interesting to study this contrastively, for example comparing spontaneous speech and literary texts, and also literary texts originally written in Mari, and literary texts translated into Mari - in many cases from strongly satellite-framed Russian.

\section{Verb-Framing Elsewhere}

This section provides a brief overview of some possible verb-framed constructions found in Uralic languages other than Mari. No claim of exhaustiveness is made.

\section{I. Udmurt}

While Turkic elements can be found throughout the Permic branch of the Uralic language family, the extent of these elements differs - between languages and between varieties of these languages. While Udmurt - along with Mari, Chuvash, Tatar, and Bashkir - has been designated as a core member of the so-called Volga-Kama Sprachbund, Komi is generally considered to be a peripheral member - subject to some convergence with its neighbouring languages, but less so than Udmurt (cf. Helimski 2003: 159). 
Converb constructions of the Turkic type are found in Udmurt, but have not been observed in Komi at all (Isanbaev 1978: 60) ${ }^{33}$. As in the case of Mari, auxiliaries labelled as "aspectual" in sources on Udmurt seem on the surface to be possible path-marking main verbs in a verb-framed verbalization of a motion event.

Udmurt (Bereczki 1984: 312)

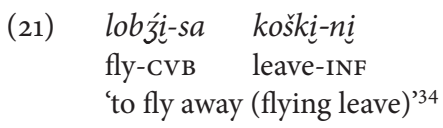

In this particular case, however, an aspectual reading would be plausible: the verb koškini could be interpreted as an aspectual marker (cf. Kel'makov 1975: 95); the pairing could in effect indicate that its subject - e.g. a bird - starts flying. It is certainly not obligatory to mark the path in this manner; my Udmurt informant produced no verb-framed constructions in our consultation.

Udmurt (Dušenkova et al. 2008: лобӟыны)

(22) tiloburdo lobź-i-z

bird fly-PST1-3SG

'The bird flew away'35

However, clear cases of verb-framed constructions can be found in Besermyan Udmurt, a language variety spoken in northern Udmurtia that has notable Tatar influences:

Besermyan Udmurt (Serdobol'skaja et al. 2012: 20)

$\begin{array}{llllll}\text { (23) }[v] u & v a ̂ l-t i & \text { pići } & \text { pi } & \text { uja-sa } & {[v] a s ́ k-e} \\ \text { water } & \text { surface-PRoL } & \text { small boy } & \text { swim-CvB } & \text { descend-3sG } \\ \text { 'Down the river swims a little boy. }{ }^{36} & & \end{array}$

Turkic-style converb constructions in general are less common in Udmurt than they are in Mari (Honti 2013: 110) and are primarily used in the more heavily Turkic-influenced Southern varieties of Udmurt (Kel'makov 1975: 95). A systematic review of the verbalization of motion events in Udmurt, especially the Southern dialects and in Besermyan, suggests itself - a possible strong dialectal difference in the verbalization of motion events between otherwise comparatively close language varieties might have value for the study of diachronic developments in the verbalization of motion events. 
Verb-Framed Motion Events in Uralic (with special attention to Mari)

\subsection{Mordvin}

Mordvin, like Komi, has been designated as a peripheral member of the Volga-Kama Sprachbund (cf. Helimski 2003: 159). Individual Turkic-style converb constructions have been observed in Erzya (but not to my knowledge in Moksha). Due to their scarcity, they are best considered to be individual Tatar loan translations, rather than a grammaticalized system (Bereczki 1984: 312). Some of the individual converb constructions seem to indicate motion events. Hence, marginal cases of Turkic style verb-framing can possibly be found in Erzya - as in the Udmurt case, the interpretation of this example might be considered controversial.

Erzya (Bereczki 1984: 312)

$\begin{array}{lll}\text { (24) varaka livt'a- } z \text { t } & \text { tu-śs } & \text { viŕ-ev } \\ \text { crow fly-cvi leave-PST1.3SG } & \text { forest-LAT } \\ \text { 'The bird flew away'37 } & \end{array}$

\subsection{Samoyedic}

The Samoyedic Kamass language, extinct since the death of its last speaker Klavdiya Plotnikova in 1989 (Klumpp 2002: 27), was subject to intense Siberian Turkic influence and adopted many Turkic structural features (ibid.: 31-33). The extensive usage of Turkic style converb constructions was studied in great detail by Gerson Klumpp (ibid.); examples of the verb-framed verbalization of motion events can be found in his survey. While a more detailed survey of the verbalization of motion events in existing materials would be necessary before this statement can be verified, it seems plausible that Kamass might qualify as a second Uralic language with a strong bias towards verb-framed constructions. It seems to be comparatively easy to find cases of verb-framed motion events in Kamass text collections.

Kamass (Klumpp 2002: 137)

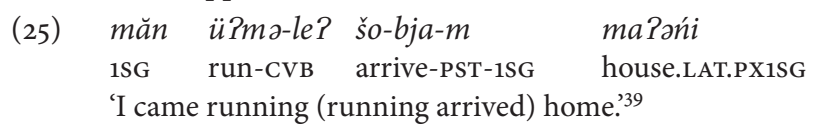




\section{Jeremy Bradley}

Kamass (Joki 1944: $93^{38}$ )

(26) dì ńi ine-bə

šl-bi, $\quad$ pe-le?

this boy horse-PX3SG.ACC mount-PST.3SG search-CvB

kalla? tür-bi,[...]

go.CVB disappear-PST.3SG

'This boy mounted his horse, left (going disappeared) to search [for ...]?:40

In Selkup, an extant Samoyedic language that has also been subject to Turkic influence (Valijärvi 2008: 175), converb constructions denoting motion events can also be found - i.e. verb-framing occurs in Selkup as well. I cannot at this point say, however, how common the phenomenon is, as the following example is the only one I could find of such a structure:

Northern Selkup (Valijärvi 2008: 169)

na nätä-t tüm-mynt̄̄tyt tìmpy-lä
that girl-PL come-narr.3PL fly-CVB
'Those girls came flying.'

It should be noted that, technically speaking, Slobin's statement does not extend to the Samoyedic languages, as he referred to Finno-Ugric, not Uralic, languages.

\subsection{Finnic}

Verb-framed constructions in Finnic can be assumed to have developed in isolation from the cases mentioned above, given the complete lack of contact between Turkic and Finnic. Jari Sivonen has discussed individual verb-framed constructions in Finnish (Sivonen 2010). In Estonian as well, a number of verbs can be found that are used in verb-framed constructions: sisenema 'to enter, to go in' (Saagpakk 1992: 847), väljuma 'to leave, to depart' (ibid.: 1132). Satellite-framed equivalents of these verbs - sisse astuma 'to step in', välja minema 'to go out', among others - seem to be overwhelmingly dominant over these in practice. Estonian's propensity to satellite-framing was presumably also supported over the centuries by contact with heavily satellite-framing German, in the course of which Estonian adopted a complex body of phrasal verbs (cf. Hasselblatt 1990). One path verb that definitely finds wide usage in Finnic languages is Finnish tulla 'to come' and its cognates - Estonian tulema, etc. 
Verb-Framed Motion Events in Uralic (with special attention to Mari)

\section{Conclusions}

Dan I. Slobin's classification of Finno-Ugric as satellite-framing holds true for most, but not all, members of the language family, as a description of a strong tendency. In my evaluation of the proliferation of verb-framed structures in Uralic, a number of structural shortcomings became apparent. Firstly, contrastive typological data on the realization of motion events in Uralic is simply not available. This makes it hard to criticize Slobin for making an unduly broad statement based on the data at his disposal. Secondly, the structure of reference materials on the individual Uralic languages makes it difficult to garner such information from the sources, even if one has access to them. Reference materials on Uralic languages tend to be written from a form-based bottom-up perspective ("What grammatical forms are there in this language and what functions do they have?") rather than a function-based top-down perspective ("What forms are used to realize a particular concept?"), making it challenging to evaluate the handling of semantic concepts in a given language. The fact that accessible annotated corpora do not exist for most Uralic languages is a further obstacle when trying to determine the prevalence of a grammatical structure in individual Uralic languages.

Recent years have seen the publication of comparative typological resources on the realization of concepts in Uralic (e.g. Wagner-Nagy \& Tamm \& Miestamo 2015 for negation). A similar survey would be desirable on the realization of motion events, given that this paper could only scratch the surface of the diversity that exists in the realization of these in the Uralic phylum.

Jeremy Bradley

Ludwig-Maximilians-Universität München Institut für Finnougristik / Uralistik

Ludwigstr. 31/III, Zi. 330 80539 München

Germany 


\section{Acknowledgements}

I would like to thank my native speaker informants for their advice and for providing me with example sentences: Emma Yakimova (Mari), Tatyana Yefremova (Mari), Elina Guseva (Mari), Nele Lond (Estonian), and Vadim Danilov (Udmurt). For obvious reasons, I could not find any Kamass native speakers to consult, but Tiina Klooster, the University of Tartu's Kamass specialist, was the next best thing, and I am grateful for her input. Likewise, Ekaterina Georgieva's input on Udmurt was quite helpful.

Ekaterina Georgieva and Christian Pischlöger gave me useful advice on Udmurt, and gave me useful pointers on sources I could consult. I am in their debt. I would also like to thank Hèctor Alòs Font for his assistance in correctly glossing Chuvash. I am grateful to Cristopher Culver, Elena Skribnik, and Monika Schötschel for their feedback on my manuscript, and to Timothy Riese for proofreading it.

\section{Notes}

1. The subscript "finite" seems like an obvious shorthand notation: clearly, the verb need not be finite if it does not occur as the main verb of a clause, e.g. "I saw the dog running out of the house."

2. Talmy uses the term Deictic verb (Talmy 2007:95) instead, but this term seems unnecessarily narrow for the purpose at hand: while path verbs can indicate a movement in reference to the deictic centre (come, go), some can also use an absolute/ topological frame of reference (ascend, descend).

3. Own creation; language data approved by Estonian native speaker Nele Lond.

4. This example was generated by an adult speaker. Younger speakers of Turkish made use of verb-framed structures as well.

5. Gerund in Uralic tradition.

6. “'Sie/er rannte ins Haus hinein.“ (wörtlich aber eher: „Sie/er begab sich laufend ins Haus hinein.")"

7. “птица залетела в окно"

8. “Карим выпрыгнул из окна"

9. “ласточка вылетела из гнезда"

10. If one assumes that semantically "light", syntactically optional information can often be omitted, one might not expect this converb to occur, as flying is the natural manner of transportation for a bird - see example 2 from Turkish. However, a perfunctory survey of my materials indicates that the manner is overwhelmingly marked by a converb in combination with all path verbs except for pörtâlam 'to return', which does not seem to co-occur with a manner-marking converb at all - in sharp contrast to other path verbs.

11. Own creation; language data approved by Mari native speaker Elina Guseva. 
12. Derived from $\beta$ olem with the partially productive causative suffix $-t \sim-d$ (cf. Alhoniemi 1985: 164-165) - see below.

13. Aktionsart according to some nomenclatures.

14. "Se esiintyy muodostamassa ns. aspektuaalista konverbirakennetta. Siinä syntaktisena pääverbinä on tekemiselle aspektuaalisen sävyn antava verbi; gerundimuoto ilmoittaa rakenteen semanttisen merkityksen. Aspektuaalisesti käytetään varsin useita verbejä. Aspektuaalisessa konverbirakenteessa ne menettävät joko kokonaan tai ainakin osaksi leksikaalisen merkityksensä. Eräissä tutkimuksissa on mainittu jopa n. 40 tällaista verbiä; [...]”

15. "[L]uettelo ei varmaankaan ole tyhjentävä[.]"

16. “ßolaš 'pudota', ßoltaš 'pudottaa', ßozaš 'laskeutua', ertaraš 'kuluttaa aikaa', ertaš 'ku-

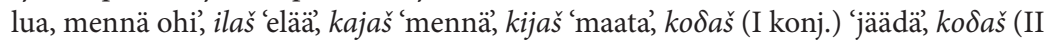
konj.) 'jättää, koltaš ‘lähettää, koštaš ‘kulkea', kudaltaš ‘heittää, kâškaš ‘heittää, lektaš 'tulla esiin', luktaš ‘tuoda esiin', mijaš ‘mennä, tulla', nalaš 'ottaa, ońćaš ‘katsoa, optaš 'latoa', puaš ‘antaa', pâštaš 'panna', pâtaraš 'lopettaa', pâtaš 'loppua', puraš 'mennä sisään', purtaš ‘viedä sisään', sitaraš ‘ tyydyttää, šinććaš (I konj.) 'istuutua, šinććaš (II konj.) 'istua, šoyalaš 'nousta seisomaan', šoyaltaš 'asettaa seisomaan', šoyaš 'seistä, šuaš (I konj.) 'saapua', šuaš (II konj.) 'heittää, šuktaš 'saattaa perille', šôndaš 'asettaa', temaš (I konj.) 'täyttyä, temaš (II konj.) 'täyttää, tolaš ‘tulla”'

17. Bereczki on occasion uses the indicative present third person singular as the lexicon form for Mari verbs, which is not in line with any established tradition for Mari. As this form is the lexicon form in Hungarian, such occurrences can be considered slips of the pen.

18. “A cseremisz szóképzésnek egy sajá[t]os formáját képviselik az ún. páros igék. A páros igék első komponense mindig határozói igenévi alakban áll, a második komponens kapja meg az idő és módjeleket, valamint a személyragokat. Az esetek túlnyomó többségében a második komponens részben vagy teljesen elveszti önállóságát, s olyképpen módosítja az ige aspektusát, mint a magyar igekötők, pl. k. čoyešten kaja, ny. čongestan keä 'elrepül' (k. čoneštem, ny. čongeštem 'repül'; k. kajem, ny. keem 'megy'); k. šortân koltem, ny. mäyran koltem 'elsírja magát' (k. šortam, ny. mäyrem 'sír'; k., ny. koltem 'dob, küld'); [...]”'

19. The nomenclature in Mari lexical sources is that two slashes - // - indicate an aspectual converb construction. This is established in the introduction of this dictionary, where this symbol is said to indicate "compound verbs with different aspectual meanings" - “составные глаголы с различными видовыми значениями” (Galkin et al. 1990-2005:I:13).

20. "zerreißen"

21. "zerbrechen"

22. "Kajaš-verbillä ilmaistaan momentaanista, tuloksellista tekemistä, [...]”

23. "Pelästyin."

24. László Honti advocates the theory of parallel development (Honti 2005, 2013).

25. Translations based on (Riese \& Bradley \& Guseva 2014-)

26. 'Lehnübersetzung: [...] tscher. tolân purem 'зайти' (eig. 'kommend hineingehen') $\leftarrow$ tschuw. kilse kěr- id." 


\section{Jeremy Bradley}

27. "Lehnübersetzung: [...] tscher. mijen tolam 'сходить, съездить куда-л'. (eig. 'gehend kommen') $\longleftarrow$ tschuw. (Ašm. 9:189) pïrsa kil- id.”

28. “уйти, уехать, удалиться” (Galkin et al. 1990-2005: II: 291)

29. “прибыть, доехать, дойти” (Galkin et al. 1990-2005: IX: 298)

30. “прийти, зайти, войти (дойдя туда) [...] поступить; устроиться куда-л.” (Galkin et al. 1990-2005:IV:61)

31. “подоспеть, прибыть; дойти, добраться, доехать куда-л.”(Galkin et al. 19902005: IV: 62)

32. “заходить, зайти (на какое-то время); побывать, посетить, навестить коголибо"(Galkin et al. 1990-2005: V: 347)

33. "Что касается составных глаголов удмуртского языка, то они, по общепринятому мнению, появились под непосредственным влиянием татарского языка. Отсутствие подобных образований в близкородственном коми языке не позволяет говорить об участии в этом процессе чувашского влияния."

34. "wegfliegen (eigtl. fliegend weggehen)"

35. "птица улетела"

36. “Вниз по реке плывет мальчик.”

37. "die Krähe flog weg in den Wald"

38. Transcription simplified by Tiina Klooster.

39. "minä juosten tulin kotia (ich kam nach Hause gelaufen)"

40. "Der Knabe setzte sich aufs Pferd, suchen ging er, [...]"

\section{Abbreviations}

$\begin{array}{ll}\text { ABL } & \text { ablative } \\ \text { ACC } & \text { accusative } \\ \text { CAUS } & \text { causative } \\ \text { CONT } & \text { continuous } \\ \text { CVB } & \text { converb } \\ \text { DAT dative } \\ \text { GEN genitive } \\ \text { ILL illative } \\ \text { INF infinitive } \\ \text { LAT lative }\end{array}$

$\mathrm{ABL}$ ablative

ACC accusative

CONT continuous

CVB converb

DAT dative

GEN genitive

INF infinitive

LAT lative

$\begin{array}{ll}\text { PL } & \text { plural } \\ \text { PR } & \text { present } \\ \text { PROL } & \text { prolative } \\ \text { PST } & \text { past } \\ \text { PST1 } & \text { past tense 1 (in Mari, Udmurt) } \\ \text { PST2 } & \text { past tense 2 (in Mari, Udmurt) } \\ \text { PX } & \text { possessive suffix } \\ \text { REFL } & \text { reflexive } \\ \text { SG } & \text { singular }\end{array}$

PL plural

PR present

PROL prolative

$\mathrm{PST}_{1}$ past tense 1 (in Mari, Udmurt)

$\mathrm{PST}_{2}$ past tense 2 (in Mari, Udmurt)

REFL reflexive

SG singular 


\section{References}

ABBYY 2014: Universal (Ru-Tt) (for ABBYY Lingvo x6) Russian-Tatar dictionary. 47,00o words. (C)1997 F. A. Ganiev. ABBYY. Москва.

Alhoniemi, Alho 1985: Marin kielioppi. Hilfsmittel für das Studium der finnisch-ugrischen Sprachen X. Suomalais-Ugrilainen Seura. Helsinki.

- 1986: Marin kielen lukemisto sanastoineen. Hilfsmittel für das Studium der finnischugrischen Sprachen XI. Suomalais-Ugrilainen Seura. Helsinki.

- 1993: Grammatik des Tscheremissischen (Mari). Helmut Buske Verlag. Hamburg.

Asbury, Anna \& Berit Gehrke \& Henk van Riemsdijk \& Joost Zwarts 2008: Introduction: Syntax and semantics of spatial P. - Anna Asbury \& Jakub Dotlačil \& Berit Gehrke \& Rick Nouwen (eds): Syntax and Semantics of Spatial P. Linguistics Today 120. John Benjamins Publishing Company. Amsterdam. 1-32.

BereczKi, GÁBOR 1984: Die Beziehungen zwischen den finnougrischen und türkischen Sprachen im Wolga-Kama-Gebiet. - Nyelvtudományi Közlemények 86. 307-314.

- 1990: Chrestomathia Ceremissica. Tankönyvkiadó. Budapest.

BERECZKI, GÁBOR ET AL. 2013: Etymologisches Wörterbuch des Tscheremissischen (Mari) - Der einheimische Wortschatz. Veröffentlichungen der Societas Uralo-Altaica 86. Harrassowitz. Wiesbaden.

BertA, ÁrpáD 1998: Tatar and Bashkir. - Lars Johanson \& Éva Á. Csató (eds): The Turkic Languages. Routledge. New York. 283-300.

Bradley, Jeremy 2015: Mari Converb Constructions: Interpretation and Translation. - Martin Hilpert \& Jan-Ola Östman et al. (eds): New Trends in Nordic and General Linguistics. Lingua \& Litterae. Walter De Gruyter. Berlin. 141-161.

Devos, Maud \& Jenneke Van Der Wal (eds) 2014: 'COME' and 'GO' off the Beaten Grammaticalization Path. Trends in Linguistics. De Gruyter Mouton. Berlin.

Driussi, PAOLO 1993: Paired verbs - serial verbs in Cheremis. - Finnisch-Ugrische Mitteilungen 16/17. 59-105.

Dušenkova et AL. 2008 = T. Р. Душенкова \& A. В. Егоров \& Л. М. Ившин \& Л. Л. Карпова \& Л. Е. Кириллова \& О. В. Титова \& А. А. Шибанов 2оо8: Удмуртскорусский словарь. РАН. УрО. Удм. ин-т ИЯЛ. Ижевск.

[Published online at <dict.komikyv.ru/index.php/index/6.xhtml>.]

Filipović, LunA 2007: Talking about Motion - A Crosslinguistic Investigation of Lexicalization Patterns. Studies in Language Companion Series 91. John Benjamins Publishing Company. Amsterdam.

Forgács, TAMÁs 2007: Ungarische Grammatik. (Third edition.) Praesens Verlag. Vienna. GALKIN ET AL. 1990-2005 = И. С. Галкин (editor in chief) et al. 1990-2005: Словарь марийского языка (I-X). Марийское книжное издательство/МарНИЙ. Йошкар-Ола. [Published online at <dict.komikyv.ru/index.php/index/8.xhtml>.]

Hasselblatt, CoRnelius 1990: Das estnische Partikelverb als Lehnübersetzung aus dem Deutschen. Veröffentlichungen der Societas Uralo-Altaica 31. Harrassowitz. Wiesbaden.

Helimski, EUgen 2003: Areal groupings (Sprachbünde) within and across the borders of the Uralic language family: A survey. - Nyelvtudományi Közlemények 100. 156-167. 


\section{Jeremy Bradley}

Hesselbäck, André 2005: Tatar \& Chuvash Code-copies in Mari. Studia Uralica Upsaliensia 35. Uppsala Universitet. Uppsala.

Honti, LÁszló 1999: Das Alter und die Entstehungsweise der "Verbalpräfixe" in uralischen Sprachen: (unter besonderer Berücksichtigung des Ungarischen). - Linguistica Uralica XXXV. 81-97.

— 2005: Uráli „páros igék”. - Folia Uralica Debreceniensia 12. 33-46.

- 2013: К вопросу о происхождении спаренных глаголов в финно-угорских языках Волжско-Камского региона. - Ural-Altaic Studies 9. 109-113.

IsANBAEV $1978=$ Н. И. Исанбаев 1978: Общее и отличительное в составных глаголах марийского и поволжско-тюркских языков. - Вопросы марийского языка. Йошкар-Ола. 59-9о.

- 1989-1994: Марийско-тюркские языковые контакты (I-II). Марийское книжное издательство/МарНИИ. Йошкар-Ола.

JOHANSON, LARS 2000: Linguistic convergence in the Volga area. - Dicky Gilbers et al. (eds): Languages in contact - Studies in Slavic and general linguistics. Rodopi. Amsterdam. 165-178.

Joki, Aulis Johannes 1944: Kamassisches Wörterbuch nebst Sprachproben und Hauptzügen der Grammatik. Lexica Societatis Fenno-Ugricae VIII. Suomalais-Ugrilainen Seura. Helsinki.

KeL'MAKOV 1975 = В. К. Кельмаков 1975: Спаренные глаголы в удмуртском языке на материале кукморского диалекта. - Bопросы удмуртского языкознания сборник статей. Удмуртский НИИ истории, экономики, литературы и языка при Совете Министров Удмуртской ACCP. Iževsk. 90-105.

KlumpP, Gerson 2002: Konverbkonstruktionen im Kamassischen. Veröffentlichungen der Societas Uralo-Altaica 58. Harrassowitz. Wiesbaden.

KoRnfilt, JAKLIN 2009: Turkish and the Turkic languages. - Bernard Comrie (ed.): The World's Major Languages. (Second Edition.) Routledge. New York. 519-544.

LANDer, Yury \& Timur Maisak \& Ekatarina Rakhilina 2013: Verbs of aquamotion - semantic domains and lexical systems. - Mila Vulchanova \& Emile van der Zee (eds): Motion Encoding in Language and Space. Explorations in Language and Space 6. Oxford University Press. Oxford. 67-83.

MiščENко 2014 = Дарья Мищенко 2014: Грамматикализация глаголов движения в башкирском языке. Proceedings of the conference “Системные изменения в языках России”. Институт лингвистических исследований РАН. Санкт-Петербург. [Published online at <iling.spb.ru/confs/syschanges2014/materials/mishchenko.pdf $>$.]

Pajusalu, Renate \& Neeme Kahusk \& Heili Orav \& Ann Veismann \& Kadri ViDER \& HALDUR ÕIM 2013: The encoding of motion events in Estonian. - Mila Vulchanova \& Emile van der Zee (eds): Motion Encoding in Language and Space. Explorations in Language and Space 6. Oxford University Press. Oxford. 44-66.

RÄSÄnen, MARTti 1920: Die tschuwassischen Lehnwörter im Tscheremissischen. Mémoires de la Société Finno-Ougrienne XVI. Suomalais-Ugrilainen Seura. Helsinki.

- 1923: Die tatarischen Lehnwörter im Tscheremissischen. Mémoires de la Société Finno-Ougrienne L. Suomalais-Ugrilainen Seura. Helsinki. 
Riese, Timothy \& Jeremy Bradley \& Elina Guseva 2014-: Mari-English Dictionary. Department of Finno-Ugrian Studies. University of Vienna. Vienna.

[Published online at $<$ dict.mari-language.com $>$.]

SAAgPakK, Paul 1992: Eesti-inglise sõnaraamat. (Third Edition.) Koolibri. Tallinn.

SAARINEN, SirkKa 1997a: Borrowed vocabulary in Mari and Udmurt dialects. SirkkaLiisa Hahmo \& Tette Hofstra et al. (eds): Finnisch-ugrische Sprachen in Kontakt. Shaker. Maastricht. 191-196.

- 1997b: Language contacts in the Volga region: Loan suffixes and calques in Mari and Udmurt. - Heinrich Ramisch \& Kenneth Wynne (eds): Language in time and space - Studies in honour of Wolfgang Viereck on the occasion of his 6oth birthday. Franz Steiner Verlag. Stuttgart. 388-396.

- 2010: Marin sanaston alkuperästä. - Sirkka Saarinen \& Kirsti Siitonen \& Tanja Vaittinen (eds): Sanoista kirjakieliin: Juhlakirja Kaisa Häkkiselle. Mémoires de la Société Finno-Ougrienne 259. Suomalais-Ugrilainen Seura. Helsinki. 335-341.

SCHÖNIG, Claus 1984: Hilfsverben im Tatarischen - Untersuchungen zur Funktionsweise einiger Hilfsverbverbindungen. Franz Steiner Verlag. Wiesbaden.

- 1997-1998: A new attempt to classify the Turkic languages (I-III). Turkic Languages 1.1. $117-133$ / 1.2. $262-277$. / 2.1. 130-151.

[Published online at <www.digizeitschriften.de/dms/toc/?PPN=PPN666048797>.]

Schroeder, Christoph 2009: gehen, laufen, torkeln: Eine typologisch gegründete Hypothese für den Schriftspracherwerb in der Zweitsprache Deutsch mit Erstsprache Türkisch. - Karen Schramm \& Christoph Schroeder (eds): Empirische Zugänge zu Sprachförderung und Spracherwerb in Deutsch als Zweitsprache. Mehrsprachigkeit 23. Waxmann. Münster. 185-201.

Serdobol'skaja ET AL. $2012=$ H. В. Сердобольская \& A. А. Ильевская \& С. А Минор \& П. С. Митева \& А. В. Файнвейц \& Н. С. Матвеева 2012: Конструкции с сентенциальными актантами в финно-угорских языках. - А. И. Кузнецова \& Н. В. Сердобольская \& С. Ю. Толдова \& С. С. Сай \& Е. Ю. Калинина (eds): Финно-угорские языки: фрагменты грамматического описания - Формальный и функициональный подходы. Studia philologica. Рукописные памятники Древней Руси. Москва. 382-475. [Published online at <www.academia.edu/8501275/>, page numbers in this paper refer to online version.]

SIVONEN, JARI 2010: Lexicalizing indirect path: Focus on Finnish motion verbs. - Elżbieta Tabakowska \& Michał Choiński \& Łukasz Wiraszka (eds): Cognitive Linguistics in Action - From Theory to Application and Back. Applications of Cognitive Linguistics 14. John Benjamins Publishing Company. Amsterdam. 241-272.

Skvorcov \& Skvorcova $2002=$ М. И. Скворцов \& А. В. Скворцова 2002: Pусскочувашский словарь. Чувашское книжное издательство. Чебоксары.

[Published online at $<$ samahsar.chuvash.org $>$.]

Slobin, DAN I. 2000: Verbalized Events: A Dynamic Approach to Linguistic Relativity and Determinism. - Susanne Niemeier \& René Dirven (eds): Evidence for Linguistic Relativity. Current Issues in Linguistic Theory 198. John Benjamins Publishing Company. Amsterdam. 107-138.

SÖDER, TORBJÖRN 2001: "Walk this way" - verbs of motion in three Finno-Ugric languages. Studia Uralica et Altaica Upsaliensia 33. Uppsala University. Uppsala. 


\section{Jeremy Bradley}

TALMY, LeONARD 1985: Lexicalization patterns - semantic structure in lexical form. Timothy Shopen (ed.): Language Typology and Syntactic Description III - Grammatical Categories and the Lexicon. Cambridge University Press. Cambridge. 57-149.

- 2007: Lexical typologies. - Timothy Shopen (ed.): Language Typology and Syntactic Description III - Grammatical Categories and the Lexicon. (Second Edition.) Cambridge University Press. Cambridge. 66-168.

Tolskaya, InNa 2007: Unifying Prepositions and Prefixes in Russian: Conceptual structure versus syntax. - Tromsø Working Papers on Language and Linguistics: Nordlyd 34/2. 345-370.

[Published online at <septentrio.uit.no/index.php/nordlyd/article/view/113>.]

VAlijÄrvi, RiItTA-LiISA 2008: Converbs in Northern Selkup. - Edward J. Vajda (ed.): Subordination and Coordination Strategies in North Asian Languages. Current Issues in Linguistic Theory 300. John Benjamins Publishing Company. Amsterdam. $167-178$.

Wade, Terence 2002: The Oxford Russian Grammar \& Verbs. Oxford University Press. Oxford.

Wagner-Nagy, Beáta \& Anne Tamm \& Matti Miestamo (eds) 2015: Negation in Uralic Languages. Typological Studies in Language 108. John Benjamins Publishing Company. Amsterdam. 